\title{
AFRODITE EM SIMÔNIDES (FRS. 541 E 575 P) ${ }^{1}$
}

\author{
GiUlianA RAgUSA* \\ Universidade de São Paulo
}

\begin{abstract}
Resumo. No corpus de Simônides, poeta mélico tardo-arcaico, só dois fragmentos trazem Afrodite: 541, em estado precário, e 575P, que se reduz a dois versos. A despeito dessas condições, há nos contornos da deusa traços que ou reiteram motivos recorrentes em suas representações poéticas arcaicas, ou acrescentam-lhes outros não anteriormente verificados. Analisá-los e a imagem de Afrodite em Simônides: eis o objetivo deste artigo.
\end{abstract}

Palavras-chave. Simônides; mélica tardo-arcaica; Afrodite; fragmentos.

D.o.I. 10.11606/issn.2358-3150.v17i1p3-33

Na mélica tardo-ARCAica de Simônides (c. 556-468/64 a.C., IlHa de CEOs), só dois fragmentos nos trazem Afrodite: 541 e 575 P. Ainda que difíceis sejam suas condições materiais, ambos revelam traços que reiteram motivos constantes nas representações da deusa na poesia arcaica, e outros não antes encontrados.

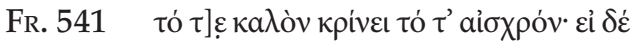

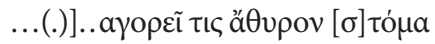

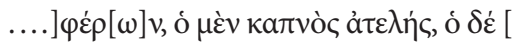

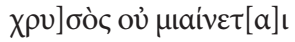

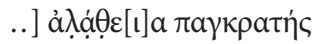

5

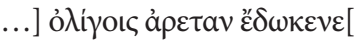

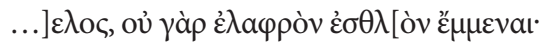

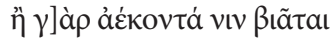

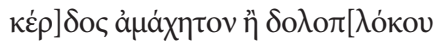

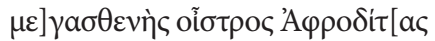

10

..].(.) $\theta a \lambda$ oí $\tau \varepsilon \varphi \iota \lambda$ ovıkiaı.

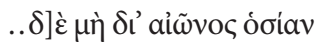

* Professora Doutora de Língua e Literatura Grega do Departamento de Letras Clássicas e Vernáculas da USP.

* Artigo recebido em 15.fev.2015 e aceito para publicação em 5.mai.2015.

${ }^{1}$ Este artigo resulta de pesquisa sobre Afrodite na mélica grega tardo-arcaica, apoiada pela Fapesp com estágio de pós-doutoramento (University of Wisconsin - Madison, EUA, 2012-2013). Para Simônides, sempre a edição Page 1962. As traduções são minhas, exceto quando indicado. 


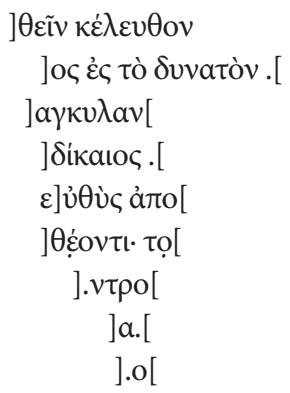

... [e o] belo (ele) distingue do feio. E se

... alguém (o) difama, a [b]oca sem portas

... carregan[d]o, a fumaça é inútil, e o ...

ou]ro não é macula[d]o,

... mas a verda[d]e é toda-poderosa

... para poucos a virtude concedeu (o deus?)

... pois não é fácil [ser] nob[re]:

o homem, contrariado, é coagido

pela [gan]ância inelutável, ou pelo moscardo

de [gr]ande força da tec[elã] de ardis, Afrodit[e]...2

... e amor às rivalidades.

... não, durante sua vida, da sacralidade

... o caminho

... tanto quanto possível ...

... tortuoso (?)

... justo ...

... d] pronto ...

(...) [versos 18-21: lacunares, ilegíveis]

Preservado no Papiro de Oxirrinco 2432 (século I d.C.), seu editor Edgar Lobel, em “2432. Simonides?" (1959, 91), atribui o fragmento a Simônides, com base em elementos da linguagem e da sua própria construção conceitual, análogos aos de outros fragmentos do poeta - notadamente, ao 542 (ou "Ode a Escopas"), que, citado no diálogo Protágoras (338e-347), de

2 Os versos 1-10 estão traduzidos em Ragusa (2013, 204-5), com comentário desenvolvido aqui. Há inclusões de "(ele)" (v. 1), “(o)" (v. 2) e "(o deus?)" (v. 6); mudanças no verso 6, de "concederam" para "concedeu"; de "excelência" para "virtude", dado o caráter ético de aretē na argumentação do Fr. 541. Nesse sentido, sigo Gentili 1964, 304; 2006, 105; Adrados 1980, 266; Campbell 1991, 433; Perrotta, Gentili e Catenacci 2007, 377; Gentili e Catenacci 2010, 167. 
Platão (c. 427-347 a.C.), de modo entrecortado e em incerta sequência, acumula volumosa e tortuosa fortuna crítica. ${ }^{3}$ Para Bruno Gentili (1961, 332), em resenha à edição de Lobel, este argumenta consistentemente; de fato, a atribuição é hoje em geral aceita. ${ }^{4}$

Assim como o Fr. 542, o 541 vem reforçar o corpus mélico que forja a imagem do Simônides sophós ("habilidoso, prudente, prático, sábio"), por conta da constante argumentação reflexiva-conceitual armada em polaridades que, como as analogias, são caros instrumentos do pensamento tradicional, também dito mítico ou arcaico. Para Emmet Robbins, em "Public poetry" (1997, 246), isso pode resultar da "associação [do poeta] com as classes dominantes de seu tempo, pois há uma longa tradição de se associar sábios e governantes (...)". Todavia, o tom sereno e grave de sua poesia, bem como seus grandes e frequentes temas de caráter ético - o da ả petri (arete "virtude"), por exemplo - parecem erigir a reputação de sophós de que goza Simônides nos antigos testemunhos. Observa-o Mary Lefkowitz, em The lives of the Greek poets (1981, 50), enfatizando que a amplitude dos comentários de Simônides ultrapassa seus versos, dados o "modo direto como nos falam" e a "precisão de suas metáforas", além do tom mais de conselheiro do que de poeta. ${ }^{5}$

\footnotetext{
${ }^{3}$ Gentili $(1964,278-9)$ observava que, "da $1^{\text {a }}$ metade do século XVIII até hoje (...), não são muitos os textos que têm sofrido tantos laceramentos e torturas, tantas diversas e contrastantes interpretações (...)" quanto o Fr. 542. Carson (1992, 110) afirma que Sócrates e Protágoras desferem, no diálogo platônico, "um ataque combinado" ao fragmento que "citam tão de todo erroneamente, interpretam erroneamente e deturpam, que a maioria dos leitores fica imaginando por que filósofos se dão ao trabalho de ler poesia". Parry $(1978,298)$ já discutia a diferença entre "o sentido original do poema e as interpretações às quais foi submetido mais tarde pelos filósofos"; similarmente, Most 1995. Babut $(1975,25)$ resume as tendências principais e divergentes de leitura do Fr. 542: "Para uns, o texto marca uma data importante na história do pensamento grego, uma etapa capital no desenvolvimento de conceitos éticos (...). Para outros, (...) deriva do gênero da consolação e se contenta em retomar, de forma brilhante e vigorosa, certo número de temas correntes na literatura anterior, apoiados em conceitos familiares da ética tradicional grega". Ver ainda Durán López 2000, 190-2; Beresford 2008. Para traduções recentes do Fr. 542 para o português: Anderson 2011; Ragusa 2013, $205-7$.

${ }^{4}$ Ver Bernardini 1969, 154-5. Lloyd-Jones $(1961,19)$ a refuta antes de aceitá-la $(1971,176$ n. 40). Bowra a aceita $(1961,332$, n. 4; 336, n. 2) antes de a rejeitar $(1963,257-67)$. Para comparação mais detalhada dos Frs. 541 e 542: Donlan 1969; Carson 1992.

${ }^{5}$ A poesia de Simônides era mercadoria cara, e várias fontes antigas afirmam ser ele o primeiro a cobrar por seus versos (Robbins 1997, 245); daí sua fama de avarento e mercenário no século v a.C. - no seguinte, porém, seu interesse pelo dinheiro se tornou positivo (Lefkowitz 1981, 52-3; Segal 1990, 226; Robbins 1997, 246). A relação acabou por dele fazer espécie de "protosofista, no momento em que os primeiros professores pagos [sofistas] se tornavam notórios no mundo grego" (Robbins 1997, 246). E a cobrança se articulou à secularização da poesia que, de dom divino, passa a profissão. Ver Detienne 1964; Detienne 2013, 87-112; Gentili 1965b, 70-2; Bernardini 1969, 145-6; Babut 1975; Bell 1978; Durán López 2000, 185-6; Carson 2002, 49-52, 102-6.
} 


\section{APRECIAÇÃO GERAL DO FR. 541}

Ouçamos, pois, a voz do sábio Simônides, entrecortada pelas lacunas do tempo no Fr. 541, cuja argumentação construída em "feixe de imagens que encapsulam o pensamento numa forma concentrada" (Henderson 1999, 97) se organiza, desde o verso inicial do texto preservado, em polaridades. Contrapondo tò kalón (o absoluto positivo) a tò aiskhrón (o absoluto negativo), o poeta parece dedicar-se a uma discussão estética; mas, como habitualmente no pensamento arcaico, a discussão é também ética, com a polaridade belo-feio ou belo-torpe, desenvolvida a seguir (vv. 2-5), apontando para o questionamento de valores heroicos aristocráticos tradicionais, crescente na era de Simônides e dali em diante, a partir do qual se vai desenhando, em contraposição à ética aristocrática que aqueles valores configuram, uma "ética mais tolerante e flexível, que considera mais inteiramente a tensão entre a probidade interior e a incerteza da fortuna" (Segal 1990, 224).

Desse modo, a valores idealizados - enfocados em plano aristocrático (vv. 1-6) - se antepõem valores relativizados em plano concreto (vv. 8-10), mais afins à imperfeita natureza humana (Gentili 1961, 340). Na transição dos planos, porém, o verso 7 enuncia a constatação-chave, gnômica, do questionamento: "não é fácil [ser] nob[re]" - ser esthlós. Dela emana uma "concepção mais humanística do homem constrangido a enfrentar todas as necessidades" (ibid.), pois tal verso "representa o limite de ruptura ideológica e estilística: dos valores absolutos se desce aos relativos, e a linguagem se dilui no movimento menos rígido e mais livre do discurso" (Gentili 1965a, 160):

A virtude ou a valentia, que, em sentido agonístico, é um sumo valor, como o belo absoluto e o ouro, é qualidade dificilmente comum entre os homens, porque a valentia absoluta não pertence à natureza humana, forçada a operar involuntariamente entre os limites de algumas "necessidades" que lhe são inerentes e às situações do viver em sociedade, como o desejo de ganho, a obsessão do amor e as ambições. (Perrotta, Gentili e Catenacci 2007, 281)

Reconstituir minuciosamente o pensamento que se vai delineando no fragmento é tarefa árdua, pois suas articulações são frágeis e dependentes de muitos suplementos, e seus termos conceituais consistem em grande desafio. Ademais, a inteligibilidade é comprometida pela precariedade dos versos 11-21. Mas, se é válida a apreensão da ideia geral da reflexão, temos que, no que tange à sua representação, Afrodite se insere em contexto filosófico de perspectiva negativa, inegável na sua qualificação (vv. 9-10) e posição destacada entre as fraquezas humanas.

A primeira delas é a difamação, aceito o suplemento [kak]agorê̂ ("difama"), proposto independentemente por dois helenistas, aceito por muitos 
comentadores do Fr. 541 e, por isso, incorporado à tradução do verso 2 que apresento, ainda que não à edição adotada do texto grego (Page 1962), que todavia o indica no aparato crítico. ${ }^{6}$ Tal difamação, feita por "boca sem portas" (áthyron stóma, vv. 2-3), pronta a "espalhar a fofoca maliciosa" (Henderson 1999, 97), é "fumaça" (kapnós, v. 3), é sem valor, vã, fosca, ineficaz (atelēs, v. 3), sem substância, embora "irritante e desagradável" (ibid.). ${ }^{8}$ A ela se somam no verso 9 a "[gan]ância inelutável" ([kér]dos amákhēton), a tormentosa e ardilosa lascívia/paixão (vv. 9-10) e a ambição ou "amor às rivalidades" (philonikíai, ${ }^{9}$ v. 11).

Pensando no verso I, sugerimos que o difamador (v. 2) é incapaz de macular o ouro (v. 4) que, em impactante contraste, é o "valor verdadeiro" (Gerber 1970, 318), real, luminoso e consistente - imagem possível do homem aceitável e bem reputado que, sendo esthlós ("nobre") até onde lhe é possível (vv. 12-14), "o belo distingue [krínei] do feio" (v. 1). ${ }^{10}$ Afinal, a "verda[d] e" (aláthe[i]a) é "toda-poderosa" (v. 5) - a verdade da boa reputação do homem pressuposto nos versos precedentes. E a "excelência" ou "virtude" - tradução mais enfaticamente ética-moral do termo aretē, essencial na poética de Simônides -, é algo que só a poucos - e certamente não ao difamador que não distingue o belo do feio - "concedeu" o deus, sujeito suposto do verbo, ${ }^{11}$ em concepção que, assim como a de Homero, entende a aretē não como algo que se conquiste ou que seja próprio a um indivíduo e não a outro, mas como dádiva divina a privilegiados, frisa Daniel Babut,

${ }^{6}$ Gentili 1961, 339; Treu 1960, 321-2. Gentili se baseia nas ocorrências do substantivo kakagoría e do adjetivo kakagóros em Píndaro (Ode pítica 2.53, Ode olímpica 1.53) e Platão (Fedro 254e). Henry $(1998,303)$ sugere [meg]alagorê, cujo sentido ("alardeia") poderia se coadunar ao Fr. 541. Mas [kak]agoreî é bem aceito e mais articulado às imagens da feiúra e da sujeira: Lloyd-Jones 1961, 19; Bowra 1963, 17; Donlan 1969, 91; Gerber 1970, 317-18; Campbell 1991, 433; Carson 1992, 117; Gentili e Catenacci 2010, 167; Perrotta, Gentili e Catenacci 2007, 377.

${ }^{7}$ A imagem, que a Henderson $(1999,97)$ parece original, se acha depois na tragédia (Sófocles, Filoctetes 188-9; Eurípides, Orestes 903) e na comédia (Aristófanes, Rãs 38). Ver Gerber 1970, 318; Perrotta, Gentili e Catenacci 2007, 282.

${ }^{8}$ Henderson $(1999,97)$ considera surpreendente a imagem "sem paralelos". Observa Gerber $(1970,318)$ que a palavra kapnós é "frequentemente usada para denotar o que não tem substância ou valor". Ver ainda Henderson (1999, 97 n.10), que faz a mesma anotação, registrando as ocorrências da palavra nesse sentido.

${ }^{9}$ Perrotta, Gentili e Catenacci 2007, 283): o substantivo ocorre na prosa clássica ática, mas o adjetivo (philónikos) já se registra em Píndaro (Ode olímpica 6.19).

${ }^{10}$ Ao entender que o sujeito da forma verbal do verso 1 é muito provavelmente o homem bom de que se ocupa o poeta desde antes do início preservado do texto, sigo Donlan $(1969,92)$, Campbell (1991, 433) e Durán López (2000, 185-6), que arrola resumidamente outras sugestões. Uma é de que o sujeito seja khrónos (tempo): Fränkel (1975, 313 n. 22; 1 ed. 1962) na 3 ed. da obra (1969), aceita em Gentili 2006, 104 n. 12; Gentili e Catenacci 2010, 335 n. 14. Outra: de que seja kairós, "justa medida": Pfeiffer 1998, 33 n. 1 (1 ed. 1968); Pellizer 1978.

${ }^{11}$ Sugestão de Gentili (1961, 339; 2006, 105), seguida, por exemplo, por Fränkel 1975, 313 n. 22 (1 ed. 1962); Donlan 1969, 94; Campbell 1991, 433; West 1994, 163. 
em "Simonide moraliste" $(1975,22)$. Tal concepção concerne à consciência da humana falibilidade (v. 7): "não é fácil [ser] nob[re] (esthlón)", pois muitas são as falhas humanas e difíceis as circunstâncias que a elas se somam, forçando o homem, mesmo contrariado, à desmedida, à falta de controle.

Para concluir essa apreciação geral, os versos 12-21 parecem falar em caminhos, justiça, correção ou prontidão, sacralidade. Não sabemos como se ligam ao todo, mas está claro que prosseguem com a reflexão sobre a natureza humana e a relação do homem com o universo. Na sugestão de Lobel (1959, 94), diriam que, "se um homem não pode manter um curso correto pela vida afora, ainda assim, se ele é tão bom quanto lhe é possível, ele pode ser chamado de virtuoso"; daí a tradução da sequência es tò dynatòn (v. 14) como "tanto quanto possível", nos passos do helenista. ${ }^{12}$

Pode-se, pois, pensar que Simônides diz no Fr. 541 não apenas que o deus concede a poucos a virtude, como também que "ser sempre pio (hósioi) com relação à deidade é prerrogativa de poucos homens" (Perrotta, Gentili e Catenacci 2007, 283). Logo, o que de melhor pode fazer o falho ser humano é respeitar a justiça $(d i ́ k e \bar{e})$ "útil" à pólis, pois ser respeitoso à justiça é "virtude 'laica', não condicionada à intervenção divina" (ibid.). Simônides propõe, desta feita, uma ética distinta da aristocrática, condizente com ideias em circulação no seu contexto cultural, notadamente, "na cultura ateniense do século v" (ibid.).

\section{A LISTA DE FRAQUEZAS HUMANAS E O LUGAR DE AFRODITE EM SIMÔNIDES}

No Fr. 541, além da difamação, outras três fraquezas constrangem o homem e o desviam do caminho da nobreza, nomeadas com precisão não encontrada no Fr. 542, em que, anota Douglas E. Gerber, em Euterpe (1970, 318), "Simônides simplesmente diz que um homem deixa de ser ảyató ['bom, nobre'] quando sofre infortúnios". ${ }^{13}$ Ei-las nos versos 9-11, segundo os quais, o homem acha-se coagido, ainda que a contragosto,

pela [gan]ância inelutável, ou pelo moscardo de [gr]ande força da tec[elã] de ardis, Afrodit[e] ... 10

... e amor às rivalidades.

${ }_{12}$ Ver as traduções de Gentili 1964, 303; Gentili 1965a, 127, 160; Gentili 2006, 105; Donlan 1969, 91; Campbell 1991, 433; West 1994, 163; Perrotta, Gentili e Catenacci 2007, 283, 377.

${ }^{13}$ Ver ainda comentário em Perrotta, Gentili e Catenacci 2007, 283. 
Dada sua elaborada inserção, pode-se afirmar, junto a William J. Henderson, em "Imagery in Simonides" (1999, 97), que "a causa central do desvio humano", na qual me concentro, é a luxúria, enunciada em termos mítico-metafóricos negativos: o "moscardo" (oîstros) poderoso ([me] gasthenēs) de Afrodite dolóplokos ("tecelã de ardis"). A imagem do moscardo e o epíteto dolóplokos são os elementos distintivos que reiteram seu status de deusa terrível, a ser temida pelos mortais, algo que a aproxima de quase todas - senão de todas - as demais deidades; terrível pelos sofrimentos que pode provocar e pelos ardis que pode tramar no mundo de éros, sua esfera de atuação. Ecoam aqui sonoridades familiares da epopeia e da mélica arcaicas - da Ilíada (c. 750 a.C.), da Teogonia (vv. 205-6) de Hesíodo (c. 700 a.C.), do Hino homérico 5: a Afrodite (c. 650 a.C.), de Safo. ${ }^{14}$

Na Ilíada (3.405), em seu embate com Helena, a quem busca levar ao leito de Páris, uma Afrodite disfarçada de velha senhora é por ela acusada de agir dolophronéousa ("urdindo enganos"), depois que a heroína a reconhece na indisfarçável beleza do colo e do pescoço divinos, que a velhice - estranha aos imortais sempiternos - não oculta. Já na Teogonia, definem-se como time ("honra", v. 203) e moîra ("lote", v. 204) de Afrodite - isto é, sua esfera de atuação e suas prerrogativas - os "enganos" (exapátas), além dos "suspiros" (oárous) e dos "sorrisos" (meidēmata) no verso 205, e do "prazer" (térpsin), do "sexo" (philótēta), da "meiguice" (meilikhíe), no 206. ${ }^{15}$ Voltando à Ilíada, no canto xIV, lembro o papel essencial de Afrodite na famosa cena de sedução de Zeus por Hera, deusa que obtém, dolosamente - porque através de mentira ardilosa -, o "cinto furta-cor" (poikilón hímanta, vv. 214-5) de Afrodite, que reúne seus poderes: o "sexo" (philótēs), o "desejo" (hímeros), os "sussurros" (oaristýs), a "persuasão [párphasis] que logra a mente cerrada dos mais sagazes" (vv. 216-7). ${ }^{16}$ Não por acaso, a ação da sedutora Hera é nomeada reiteradamente na forma verbal que Helena usa para a ação da sedutora Afrodite no canto III - dolophronéousa -, em verso formular. ${ }^{17}$ Por fim, no verso 38 do Hino homérico $v$, a sedutora Afrodite, que enganará o herói Anquises com palavras, gestos e alteração de sua aparência, a fim de levá-lo

\footnotetext{
${ }^{14}$ Para os fragmentos de Safo, sempre a edição Voigt 1971.

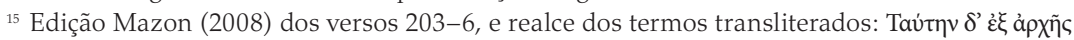

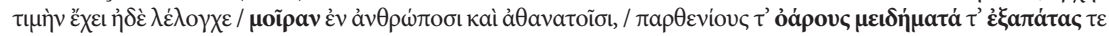

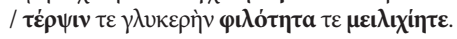

${ }^{16}$ Edição Mazon (2002b) da Ilíada (14.214-7), com realce dos termos transliterados: j̃ kaì ảmò

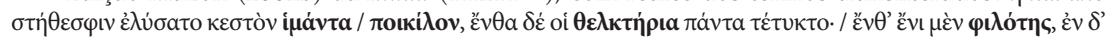

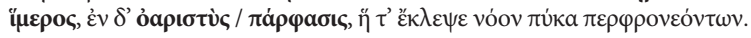

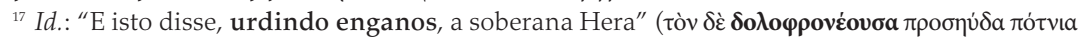

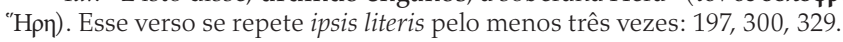


ao leito, é retratada como a deusa que "engana a mente cerrada" (pykinàs phrénas exapaphoûsa) do próprio Zeus. ${ }^{18}$

Fato inconteste, o ardil é próprio à sedução e, portanto, à deusa que a rege, a Afrodite dolóplokos do Fr. 541 de Simônides, mas, antes, do Fr. 1 ("Hino a Afrodite") $)^{19}$ de Safo (c. 630-580 a.C.), em sua primeira ocorrência ${ }^{20}$ :

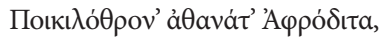

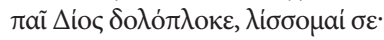
De flóreo manto furta-cor, ó imortal Afrodite, filha de Zeus, tecelã de ardis, suplico-te:

Nessa invocação, que deve identificar a deidade a quem se dirige quem suplica, dois dos quatro epítetos de Afrodite são talvez cunhagens sáficas: Poikilóthron' (v. 1) e dolóploke (v. 2). Estes se sobressaem, na medida em que partilham o universo do difuso, do que não se revela inteiramente, do intricado e múltiplo, enfim, do erotismo, regido por Afrodite. ${ }^{21}$ Nesse sentido, cabe salientar a articulação entre poikiló-thron' e doló-ploke, pois dólos e poikílos integram o campo semântico da mētis,

uma forma de pensamento, um modo de conhecer; ela implica um conjunto complexo, mas muito coerente, de atitudes mentais, de comportamentos intelectuais que combinam o faro, a sagacidade, a previsão, a sutileza de espírito, o fingimento, o desembaraço, a atenção vigilante, o senso de oportunidade, habilidades diversas, uma experiência longamente adquirida; ela se aplica a realidades fugazes, móveis, desconcertantes e ambíguas, que não se prestam nem à medida precisa, nem ao cálculo exato, nem ao raciocínio rigoroso. (Detienne e Vernant 2008, 11; 1 ed. 1974)

Esse campo da mētis ("inteligência astuciosa") é, portanto, caracterizado pelas ideias do ágil, do flexível, do oblíquo, do ambíguo, do múltiplo, da estratégia que usa o raciocínio para vencer a força bruta, do dolo, do ardil, da poikilía - do embaralhamento e da mistura de luzes, de cores, de formas, que impedem a imediata, nítida e reta captação daquilo que é poikílos. ${ }^{22}$ Isso significa que os dois epítetos sáficos, como de resto a tradição poética desde os poemas homéricos, lançam Afrodite e seu universo no plano do engano, do ambíguo, do ondulante. Afinal, a sedução é um jogo em que o sedutor manipula a si próprio - sua aparência, sua fala -, a

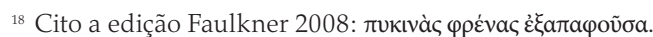

19 Tradução e estudo: Ragusa 2005b, 261-328, 424-6; Ragusa 2011, 73-6; Ragusa 2013, 100-5.

${ }^{20}$ Há mais duas ocorrências do epíteto, sempre dado a Afrodite: o mélico Fr. 949 P (anônimo) e o fragmento elegíaco 1386 W, da Teognideia, que emula a poesia de Teógnis (c. 550-480 a.C.).

${ }^{21}$ Para estudo detido desses elementos e do cenário que desenham: Ragusa 2005b, 153-72, 261-337.

${ }^{22}$ Para estudo detalhado da mêtis e de noções correlatas, ver Detienne e Vernant 2008 (1 ed. 1974). 
fim de persuadir o objeto de seu desejo a lhe ser recíproco, enredando-o em trama inescapável.

Enredar, aliás, é verbo eloquente no caso de doló-ploke, uma vez que a segunda metade do composto o associa à arte de tecer fios de tramas que enredam as vítimas de éros. E essa arte, feminina por excelência, é desde a tradição dos poemas homéricos metáfora para arte de enganar eroticamente, de seduzir. Lembre-se na Odisseia a ninfa Calipso (5.61-2) e a feiticeira Circe (10.220-4), que cantam e tecem, enquanto seduzem e enganam; e Penélope (2.93-110, 19.136-56, 24.129-48), que fia durante o dia o tapete que desfia durante a noite, enganando os pretendentes que a assediam. Lembre-se ainda a ambígua Helena, que surge na Ilíada (3.125-8), pela primeira vez, a tecer numa trama a guerra que se desenrola entre gregos e troianos, por causa de sua beleza irresistível, da paixão avassaladora de Páris, do engano do marido dela, Menelau. ${ }^{23}$

O dolo está, portanto, duplamente marcado em dolóplokos, síntese do recorrente motivo do engano amoroso, variamente integrado às representações de Afrodite. Logo, quando Simônides a qualifica com esse epíteto, dialoga com a tradição sáfica e/ou poética a partir da qual se projeta a concepção de éros. Mais: dialoga com a imagem cultual de Afrodite na Grécia, deusa "que acima de tudo preside sobre a sexualidade", resume Vinciane Pirenne-Delforge e Gabriella Pironti, em "Greek cults of Aphrodite" (2011, 43) - sexualidade, completam elas, que envolve a sedução potencialmente enganadora, bem como a força erótica potencialmente ruinosa.

Assim sendo, a referida concepção de éros é positiva, porque a experiência erótica produz prazer e doçura, e negativa, porque lida com o engano, a manipulação, a privação da clareza da mente, a perda do controle racional sobre o instintivo, os apelos do corpo, o desejo que precisa ser saciado, a falta que a tudo domina e que se busca obsessivamente suprir - eis o sentido básico do termo éros. ${ }^{24}$ Mas cada poeta intensifica diferentemente essas

\footnotetext{
${ }^{23}$ Para a mētis (astúcia ou inteligência astuciosa) feminina: Holmberg 1997. Para o tecer e sua relação com o universo feminino e com a poesia: Snyder 1981; Bergren 1983; Jenkins 1985; Pantelia 1993. Cabe mencionar que há na iconografia uma tradição de representação de Afrodite como tecelã; ver Suhr $(1960,1963,1969)$, que destaca figuras sobretudo da era helenística (323-31 a.C.). Bundrick $(2008,295)$ ressalta o modo como o tecer, na era clássica (c. 480-323 a.C.), se associa a figuras ainda mais elevadas do que Circe ou Calipso, pois é ação das Nereidas, de Afrodite e suas companheiras habituais. Suhr (1963) discute a iconografia desse período, que trazem a deusa como tecelã, motivo que remonta ao Oriente.

${ }^{24}$ Carson 1998, 10: "A palavra grega éros denota 'a falta, a carência, o desejo do que está faltando'. O amador quer o que não tem. É por definição impossível a ele ter o que quer, se, assim que o obtém, não mais lhe falta". Esse dilema intrínseco a éros torna sempre tormentosa a experiência erótica, incompleta, frustrante; afinal, ninguém jamais deseja o que não se foi, o que não lhe escapa, o que não lhe falta. Notável, nesse sentido, é que a poesia erótica canta a perseguição, a sedução, a capitulação, o enlace erótico - e nada mais. Não há o depois, se o desejo é saciado.
} 
polaridades, não raro a partir das mesmas imagens, dos mesmos termos. Dolóplokos, exemplo que interessa aqui, é positivo na prece de Safo, em que a Afrodite chamada à batalha erótica deve ser a que agrega os mais eficazes elementos de sedução. Em Simônides, porém, é negativo, pois Afrodite se destaca na lista de fraquezas (vv. 8-11) que limitam a capacidade humana de ser nobre (v. 7). Diz Eleonora Cavallini, em Presenza di Saffo e Alceo nella poesia greca fino ad Aristofane (1986, 28): para o poeta, éros é "força nociva e alucinada, que consome a energia do homem, dificultando sua jornada

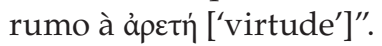

Vejamos mais de perto a imagem metafórica do tormento erótico empregada por Simônides - o oîstros de Afrodite, seu potente moscardo. Na Odisseia (22.300), o termo grego nomeia o moscardo que ataca e alucina o gado, recorda Henderson $(1999,97)$; em duas tragédias, ${ }^{25}$ se insere em contexto erótico, mas mantendo o eco odisseico: nelas, a ciumenta Hera o envia para atormentar e pôr em fuga a jovem Io, transformada em novilha, por quem Zeus se tomara de desejo e com quem cometera mais um de seus célebres adultérios. Como bem resume Lobel (1959, 94), o substantivo oîstros "e seus derivados são aplicados para qualquer frenesi" - como nas citadas ocorrências -, "mas não comumente (...) para o do amor, como em Eurípides (Hipólito, v. 1300) e aqui", no Fr. 541 de Simônides, anteriormente ao poeta trágico (c. 482-406 a.C.). De fato, no Hipólito, o oîstros é imagem para o efeito da ação de Afrodite sobre Fedra, a quem a deusa leva à paixão pelo seu enteado, o jovem filho de Teseu, nomeado no título, para vingar-se do privilégio exclusivamente concedido por Hipólito a Ártemis, conforme essa deusa explica nos momentos finais da tragédia. Em Simônides, ô̂stros é a força erótica, destacada fraqueza humana, impeditiva à perfeição que não pertence aos mortais, obstáculo no caminho da nobreza e virtude humanas. Ambos Simônides e Eurípides equiparam o efeito da paixão ao "aguilhão do moscardo, que causa dor, loucura e leva à fuga", ressalta Henderson (1999, 97-8). Trata-se de visão tradicional: éros é, no imaginário grego, "uma invasão, uma doença, uma insanidade, um animal selvagem, um desastre natural", frisa Anne Carson, em Eros, the bittersweet (1998, 148), que vem a "provocar o colapso, consumir, queimar, devorar, exaurir, entontecer, picar, aguilhoar (...)".

Além da tragédia, que lhe é posterior, a imagem do poderoso oîstros de Afrodite dolóplokos, no Fr. 541 de Simônides - isto é, da obsessiva loucura da lascívia ou da paixão, que desviará o homem bom "de seu verdadeiro curso" (Henderson 1999, 98) - traz à memória outros mélicos que vale

${ }^{25}$ Suplicantes (vv. 541-3) e Prometeu acorrentado (vv. 567-9), de Ésquilo. Ver ainda Héracles furioso (v. 862) e Ifigênia em Táuris (v. 1456), de Eurípides; Traquínias (v. 1254), de Sófocles. 
mencionar, no que concerne à alteração radical do estado mental de quem deseja. Novamente, o Fr. I de Safo, em cujo verso 18 Afrodite qualifica o thýmōi ("coração") da suplicante como mainólai ("enlouquecido"). E ainda estes pequenos fragmentos sáficos abaixo ${ }^{26}$ :

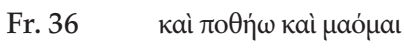

... e desejo e enlouqueço [maómai]...

Fr. 47

"Е

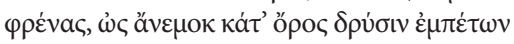

... Éros sacudiu meus sensos,

qual vento montanha abaixo caindo sobre as árvores...

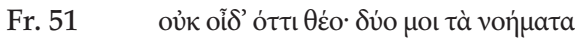

Não sei o que faço: duas são as minhas mentes...

E Íbico ${ }^{27}$ (ativo em c. 550 a.C.), em cuja poesia a linguagem erótica é sobretudo negativa igualmente à de Simônides, mas à diferença da de poetas anteriores, como Safo, e contemporâneos, como Anacreonte, nos quais éros oscila entre positivo-negativo. Bem o mostram dois fragmentos ibiqueus. O 286, ${ }^{28}$ em que um deus Bóreas (vento frio do Norte), plasmado na imagem de Eros, acossa a persona:

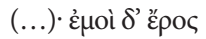

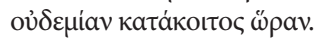

$\dagger \tau \varepsilon \dagger \dot{u} \pi$ ò $\sigma \tau \varepsilon \rho о \pi \tilde{a} \varsigma \varphi \lambda \dot{\varepsilon} \gamma \omega \nu$

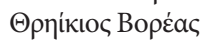

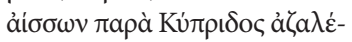

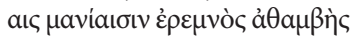
$\dot{\varepsilon} \gamma \kappa \rho \alpha \tau \dot{\varepsilon} \omega \varsigma \pi \varepsilon \delta \dot{\theta} \theta \varepsilon v \dagger \varphi \nu \lambda \alpha \dot{\sigma} \sigma \sigma \varepsilon \dagger$

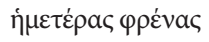

(...) Mas, para mim, a paixão não repousa em nenhuma estação. E, com raios marcando o caminho, o trácio Bóreas, voando veloz da casa de Cípris, com crestantes $\quad 10$ loucuras, sombrio, descarado, com mão firme, desde o fundo, vigia meus sensos...

${ }^{26}$ Todos os fragmentos em tradução de Ragusa 2011, 106 [Fr. 36], 85 [Fr. 47], 107 [Fr. 51]. Os Frs. 36 e 47 também em Ragusa 2005b, 287-8, 441, 444; Ragusa 2013, 117, com comentários.

${ }^{27}$ Para os fragmentos de Íbico, sempre a edição Davies 1991.

${ }^{28}$ Tradução e comentário: Ragusa 2013, 165-7; estudo em Ragusa 2010, 394-418. 
E no $287,{ }^{29} \mathrm{em}$ que vemos Eros, aliado a Afrodite, em ação:

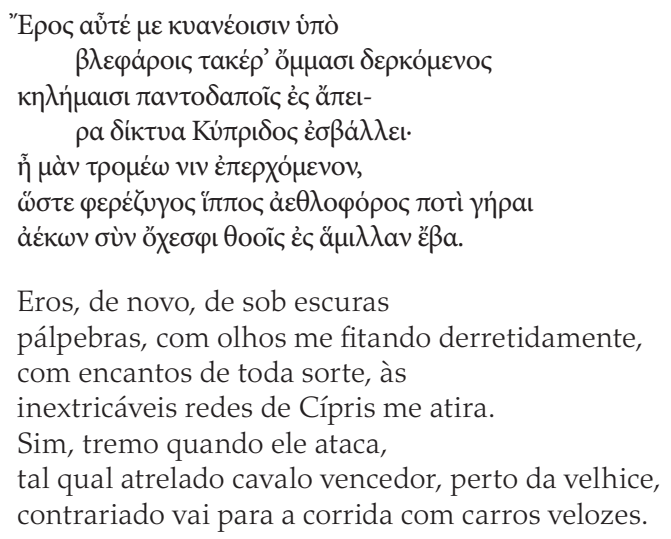

Em "Aspetti del rapporto poeta, committente, uditorio nella lirica corale greca" (1965b, 78-80), Gentili frisa, sobretudo com base nos fragmentos acima citados, como a experiência erótica se torna negativa em Íbico, distinguindo-o na tradição dessa temática, pois em sua poesia éros jamais "concede a possibilidade de abandono ou de êxtase, como na experiência sáfica, nem conhece a alegria sapiente e lúdica de Anacreonte, nem oscila na polaridade do contraste entre impulso emotivo e intelecto, nem se resolve no paralelismo do 'amo e não amo' [Anacreonte, Fr. 428 P]" (Gentili 1965b, 78). Adiante, conclui, tendo em vista o Fr. 541 de Simônides - os versos 9-10 e, neles, a caracterização de éros a partir da qualificação da deusa que sobre ela preside, Afrodite:

Essa visão de Eros, o deus, terrível pela loucura que provoca na vida humana, mágico poder que impõe ao homem uma conduta que lhe é estranha, achava ressonância (ainda não posta em relevo pela crítica) na cultura tardo-arcaica, se Simônides podia representar a paixão amorosa como moscardo (oĩ $\tau$ tpoc) de Afrodite, como poder divino obsessivo, capaz de limitar àquele de quem se apodera a possibilidade de ser valente nos termos da ética aristocrática do àyatós [bom, nobre]. Eis o começo da trajetória rumo à opinião que se tornará corrente na cultura do século v a.C., de Eros demônio destruidor, a ser temido pela catástrofe que suscita com suas loucuras eróticas, e do amor como doença, como elemento negativo da púoıৎ [da natureza], ou como fato do "eu" irracional. (Gentili 1965b, 79-80) ${ }^{30}$

Todos esses elementos estão na linguagem erótica desde a era arcaica, porém inseridos na polaridade sintetizada no amálgama sáfico glykýpikros

\footnotetext{
${ }^{29}$ Tradução e comentário: Ragusa 2013, 167-9; ver estudo em Ragusa 2010, 480-507.

${ }^{30}$ Ver também Cavallini 1986, 28; Fuentes 2002, 14-5, 17.
} 
- "doce-amargo" (Fr. 130). ${ }^{31}$ Se prevalecem dor, sofrimento e tormento, há também doçura, prazer. Mas não em Íbico, que radicaliza a linguagem negativa, nem em Simônides, que empresta traços do desenho sáfico de Afrodite ao qualificá-la como dolóplokos - em consonância com uma tradição poética reconhecível em vários gêneros desde a épica homérica, em que figuras femininas sedutoras são perigosamente ardilosas -, pintando-lhe e a éros com as sombrias tintas de Íbico, prevalentes na era clássica. Mostra, ainda, o Fr. 575 de Simônides, o outro único em que figura a deusa, em imagem que não se altera.

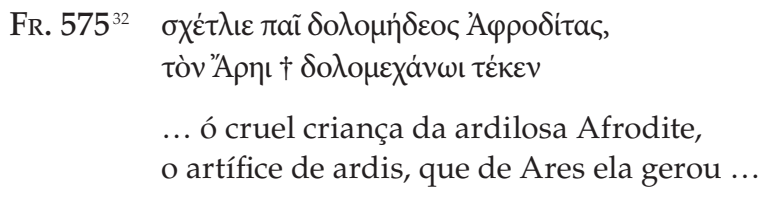

A fonte desse fragmento é um escólio ao verso 26 do Livro iII da Argonáutica, de Apolônio de Rodes (c. 295-230 a.C.), ${ }^{33}$ no passo em que Hera sugere a Atena que busquem em Afrodite (Cípris) e Eros, filho da deusa, auxílio para que Jasão aceite a colaboração de Medeia no feito de arrebatar o velocino de ouro (vv. $25-8)^{34}$ :

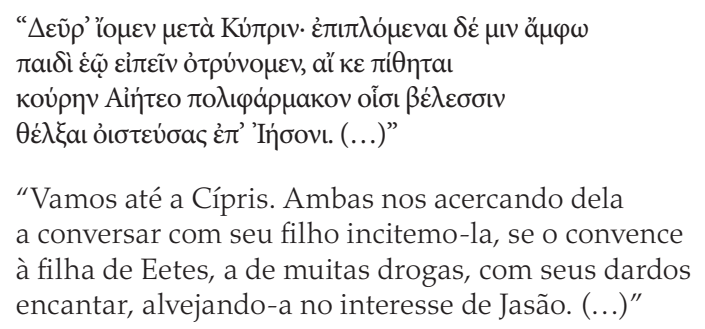

O escoliasta arrola em seu comentário outras genealogias mais antigas do deus ${ }^{35}$ : a da Teogonia (vv. 116-22), que faz de Eros um dos quatro deuses primordiais, ao lado de Gaia, Urano e Tártaro, simbolizando a "a união sexual e procriação que irá povoar o mundo" (Gantz 1996, 3, vol. 1); e a de

\footnotetext{
${ }^{31}$ Tradução e comentário: Ragusa 2005b, 268, 445; Ragusa 2011, 85-6; Ragusa 2013, 127-8.

32 Tradução e comentário: Ragusa 2013, 210. Evidencio aqui, porém, algo indicado na publicação anterior: a compreensão do epíteto do verso 2 como atribuído a Eros, e não a Ares, contrariando a edição Page (1962) do Fr. 575 de Simônides. Ver adiante essa argumentação e a discussão bibliográfica.

${ }^{33}$ Para o escólio: edição Wendel 1958.

${ }^{34}$ Edição: Gillies 1928. Tradução: Rodrigues 2005, 131.

${ }_{35}$ Discuti esse tema em estudo anterior (Ragusa 2010, 452-5).
} 
Safo, segundo a qual ou Eros é filho de Gaia e de Urano, ou deste e de Afrodite. ${ }^{36}$ Para Barbara Breitenberger, em Aphrodite and Eros (2007, 165), a crer nesse testemunho, a poeta teria sido a primeira "a ter chamado Eros, explicitamente, de 'filho de Afrodite' - logo, a tê-lo relacionado geneticamente à esfera mais jovem do Olimpo", dado que a deusa é filha de Zeus, na tradição prevalente. Além disso, prossegue, Safo teria, como Hesíodo - talvez uma de suas fontes -, inserido Eros na "tradição cosmogônica primordial", que ecoa nas figuras de Urano e Gaia. Há, ainda, a genealogia dada em Alceu, contemporâneo a Safo, em que Eros é filho de Íris e Zéfiro (Fr. 327). ${ }^{37}$

Ao contrário do que se consolidou em nosso imaginário, e até onde permite afirmar o corpus poético arcaico que resta, só em Simônides se explicita a genealogia de Eros como filho de Afrodite. Os poucos textos que relacionam essas deidades, além dos já referidos neste artigo, quando permitem dizer algo sobre os termos dessa relação, retratam Eros como servo de Afrodite, sua superior hierárquica: dois fragmentos da mélica de Álcman, ${ }^{38}$ poeta ativo em fins de 600 a.C., e dois da de Anacreonte. ${ }^{39}$ Seja como for, é bom atentar para o fato de que, "a relação que a representação mitológica tece entre Afrodite e Eros é normalmente de subordinação", resume Claude Calame, em Eros na Grécia antiga (2013, 26), e "a deusa sempre domina o jovem Eros cuja figura tende ou à divinização ou, no final da época arcaica, à multiplicação". De fato, no último poeta tardo-arcaico mais representativo, Píndaro (c. 518-446 a.C.), no Fr. 122, ${ }^{40}$ Afrodite não é mãe de Eros, mas dos Erotes, projeção coletiva do deus, menos frequente, difundida especialmente na iconografia desde o fim do século vi a.C. ${ }^{41}$

Assim, a primeira, a mais antiga e a única atestação segura de Eros filho de Afrodite se dá no Fr. 575 de Simônides ${ }^{42}$; e nessa genealogia que ganhará proeminência da era clássica em diante, o deus Eros, cujo culto na Grécia se fortalece sobretudo a partir do século vi a.C., se torna "membro legítimo da família Olímpia" (Breitenberger 2007, 168). Mas não se esgota nisso o interesse despertado pelo breve Fr. 575. Outros elementos nele se

${ }^{36}$ Fr. 198 de Safo, composto por dois escólios: o que cita o Fr. 575 de Simônides, e outro, ao Idílio 13.1-2c, de Teócrito (c. 300-260 a.C.).

${ }^{37}$ Para Alceu: edição Voigt 1971. Tradução e comentário: Ragusa 2010, 454; Ragusa 2013, 90-1.

${ }^{38}$ Frs. 58 e 59, sempre na edição Davies 1991. Ver estudo: Ragusa 2010, 439-76; Ragusa 2013, 60-3.

${ }^{39}$ Frs. 346 (fr. 4) e 357, sempre na edição Page 1962. Ver Ragusa 2010, 507-56; Ragusa 2013, 181-4. Menciono ainda de Safo o Fr. 159, em que, segundo Máximo de Tiro (c. 100 d.C., Oração

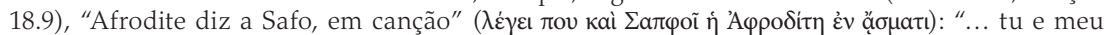

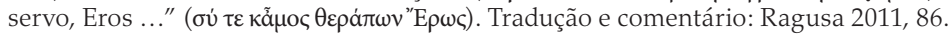

${ }^{40}$ Edição Snell 1964.

${ }^{41}$ Ver Rosenmeyer 1955, 16; Gantz 1996, 4, vol. 1.

${ }^{42}$ Segundo o escólio à Argonáutica, cujos dizeres consistem no Fr. 324 de Íbico, neste Eros seria filho de Ares e Afrodite antes de Simônides. Mas não temos o texto em que veríamos isso. 
destacam: Eros invocado como "cruel criança" (skhétlie pâ̂, v. 1); os epítetos de Afrodite e Ares e a imagem da relação erótica entre eles. Somados à própria genealogia, esses elementos todos configuram a imagem profundamente negativa da experiência erótica, reiterando a visão dada nos versos 9-10 do Fr. 541 de Simônides.

\section{EROS, O INFANTE TERRÍVEL}

Christine Kondoleon, em "Eros, the child of Aphrodite" (2011, 107), observa como esse deus tem abundante iconografia, mas "poucas referências escritas nas fontes antigas, epigráficas ou literárias", bem ao contrário do que se passa com Afrodite. E sabemos que seus cultos só começam a ser atestados bem tardiamente, se comparado ao caso da deusa. ${ }^{43} \mathrm{Na}$ iconografia, diz a estudiosa, "o mais antigo vestígio visual da relação entre Eros e Afrodite está numa frisa do Partenão (século v a.C.), na qual o menino alado repousa sobre os joelhos de sua mãe, enquanto enfia sua mão direita sob sua veste mais externa" (p. 108). Mas não há tão numerosa representação visual desses deuses juntos quanto há do deus sozinho - nos séculos vi e v a.C., notadamente como belo adolescente alado, retratado amiúde com instrumentos e brinquedos (pp. 111-2).

No caso de fontes escritas, a primeira ocorrência poética do motivo de Eros menino/infante se dá no Fr. 58 de Álcman ${ }^{44}$ :

'А

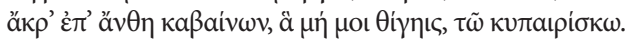

Afrodite não está, mas selvagem Eros que, qual menino, brinca, a descer sobre o topo das flores - não me vás nelas tocar! - da galanguinha.

Na ausência de Afrodite, Eros paîs ("menino") que, como tal, paísdei ("brinca"), surge como infante terrivelmente ameaçador no qualificativo márgos ("selvagem"); daí a frase parentética do verso 2. Não discutirei aqui o sentido da cena, pois já o fiz detidamente em estudo anterior (Ragusa 2010, 439-65). Interessa-me agora Eros infante, condição frisada em <paîs>

${ }^{43}$ Afirma Pirenne-Delforge $(1994,72)$ a raridade dos cultos gregos oficiais ao deus. Breitenberger $(2007,141)$ acredita que as evidências indicam "que Eros só gradualmente se tornou um deus personificado de culto. Pode-se, neste caso, aceitar que desenvolvimentos cultuais sejam fortemente influenciados pelas características poéticas de Eros como um deus envolvido nos assuntos privados de amor, tal qual ele é retratado na literatura antiga desde o final do séculovi a.C.".

${ }^{44}$ Ver nota 38. Retomo aqui elementos de estudo anterior, filtrados pela sua pertinência ao artigo. 
paísdei (v. 1), e infante perigoso, frisada no adjetivo que precede seu nome, márgos, só reencontrado nessa atribuição ao deus na poesia helenística (c. 323-31 a.C). ${ }^{45}$ Seja qual for a brincadeira de Eros, ela nada tem de inofensiva: márgos não se acha senão em contextos negativos, ${ }^{46} \mathrm{e}$ marca no deus a violência, a selvageria erótica, que sua infantilidade - e inconsequência - só agravam. Tal infantilidade é constatada em Álcman pela primeira vez na poesia grega antiga, e a imagem do deus menino será alternada, na iconografia arcaica, com a imagem mais frequente do deus adolescente, até que, em tempos helenísticos, aquela prevaleça sobre esta, tanto na poesia quanto na iconografia em que o deus surge constantemente ao lado de Afrodite nutriz (kourotróphos), que o amamenta. ${ }^{47}$

Depois de Álcman, só se acha Eros infante no Fr. 575 de Simônides ${ }^{48}$ - e infante terrível, novamente, como o qualifica skhétlie ("cruel"), que abre a invocação do deus, precedendo o substantivo paîs que, afirma o escólio à Argonáutica, identifica Eros..$^{49} \mathrm{O}$ adjetivo é negativo, como márgos, e é majoritariamente atribuído, na poesia homérica e na hesiódica, a heróis ou, menos vezes, a deuses, em contexto marcial, anota Carmen B. Fuentes, em "La expressión del sentimento amoroso em Simónides" (2002, 15). Eloquente é tal adjetivo, portanto - mais do que se possa imaginar, pois já anuncia, antes da genealogia, o enlace éros-guerra, que lança ao mundo do erotismo a violência, a letalidade e o sofrimento característicos do campo de batalha.

\section{AFRODITE E ARES, ÉROS E MÁKHË: ENLACES E DESENLACES ${ }^{50}$}

Volto à Ilíada, ao canto 3 aqui já lembrado. Exercendo suas prerrogativas, Afrodite seduz Helena a ir ao encontro de Páris que no leito a espera, para a ela se enlaçar em sexo prazeroso (v. 441). Primeiro, a deusa a engana, assumindo a identidade de uma velha senhora sua conhecida. Percebendo, porém, a mais bela mortal o truque de Afrodite, cuja beleza o disfarce não pode ocultar inteiramente, Helena se rebela e se recusa a obedecê-la, tratando-a sem a devida reverência. Eis a resposta da irada deidade:

${ }^{45}$ Ver Calame 1983, 555.

${ }^{46}$ Calame $(1983,556)$, que ilustra essa afirmação com exemplos como o da Electra (v. 1027), de Eurípides, em que é usado para a adúltera Helena.

${ }^{47}$ Ver Nock 1924, 153; Calame 1983, 555; Stampolidis e Tassoulas 2009; Kondoleon 2011.

${ }^{48}$ Há o duvidoso Fr. 378, de Anacreonte, em que paîs é suplemento ao verso 2, nem sempre aceito, à diferença de paîs (v. 1) no Fr. 58 de Álcman, respaldado em paísdei (Ragusa 2010, 452, 440).

${ }^{49} \mathrm{Na}$ Teognideia, já referida neste artigo, Fr. 1231, Eros recebe o mesmo epíteto.

${ }^{50}$ Em Ragusa (2005b, 322-8) discuti o tema que ora repenso, atualizando a bibliografia pertinente. 


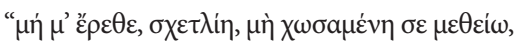

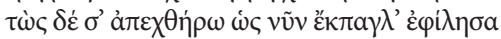

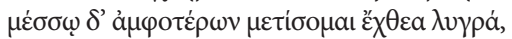

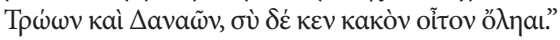

"Miserável, não me provoques. Que, colérica, não te abandone, que eu não te odeie como agora te amo violentamente; tramarei ódios lutuosos no meio de ambos, troianos e dânaos, e tu perecerás de maligno destino".

Em Entre ciel et guerre, Pironti $(2007,209)$ observa que, embora seja "uma potência de união", Afrodite "recorre de bom grado à violência para exercer suas prerrogativas de deusa preposta de éros e da mixis [mistura] sexual", como bem mostra o exemplo acima, ao qual inúmeros outros poderiam ser somados; completa Pironti: "Vista desse ponto de vista e liberta de suas etiquetas, Afrodite não parece ser oposta a Ares". Não por acaso a poesia os enlaçou, a iconografia os associou, os cultos os aproximaram, ainda que, para nós, de modos e com significados algo nebulosos, difíceis de apreender.

A primeira passagem de poesia arcaica em que Afrodite e Ares estão envolvidos eroticamente é a célebre canção do aedo Demódoco, que narra com muito humor, na Odisseia (8.266-366), o adultério entre eles - ela, esposa de Hefesto. ${ }^{51} \mathrm{Na}$ Teogonia hesiódica, Afrodite nasce da castração de Urano por seu filho Crono (vv. 188-206), ação violenta e dolosa, traiçoeira, ardilosa, geradora tanto da união dos contrários - o sexo-, que ela, nascida da espuma de sêmen e água marinha, representa, quanto da desunião radical, de que advém a guerra representada pelos nascidos do sangue do membro castrado, que respinga na áspera terra - os Gigantes, as Ninfas Freixos e as Erínias (vv. 183-7), deuses sombrios ligados aos crimes e à guerra - logo, ao mundo de Ares, deus da carnificina da batalha. Significativamente, adiante ressurge Afrodite como mãe de prole gerada de Ares: Fóbos (Pânico) e Deímos (Medo), partícipes do mundo paterno da morte e da destruição, e Harmonia, partícipe do mundo materno do sexo e da vida (vv. 933-7). ${ }^{52}$ Para Pironti (2005, 171), em "Aphrodite dans le domaine d'Arès", essa passo do poema hesiódico confere ao casal Afrodite-Ares o status de articulação forte no Olimpo. Por fim, na Ode pítica 4.87-8, de Píndaro, Ares é consorte de Afrodite.

\footnotetext{
${ }^{51}$ Muitos estudos e distintas interpretações discutem essa canção. Destaco as que nem o moralizam, nem o subestimam: Detienne e Vernant 2008, 252-5; Alden 1997, que sintetiza tendências de leitura; Braswell 1982; Brown 1989; Olson 1989; Konstantakos 2012, centrado nas relações da narrativa com tradições folclóricas sobre o adultério. Teffeteller (2010) estuda relações da canção com cena similar na tradição hitita. Noto que na Ilíada (5.357) Afrodite e Ares são irmãos e aliados.

${ }^{52}$ Ver Ragusa 2005a (2001), 109-30. Na bibliografia mais recente, destaco a análise de Pironti (2007, 21-104) sobre Afrodite e a violência no poema hesiódico.
} 
Dados esses exemplos, Pironti $(2005,171)$ afirma acertadamente:

Não é correto encerrar Afrodite no papel de esposa adúltera de Hefesto, seguindo o testemunho da Odisseia: Hefesto não aparece quase nunca ao lado da deusa fora desse episódio. No relato de Demódoco, ele não desempenha seu papel de marido senão no momento de encontrar Afrodite nos braços de Ares, o companheiro habitual da deusa, e de aprisionar os amantes em elos indestrutíveis. Além do mais, o mito nada faz senão confirmar os "elos" que unem Afrodite e Ares, levando-os mesmo a desafiar as leis do casamento.

Também na tradição iconográfica do século vir a.C. em diante, Ares e Afrodite são amantes ${ }^{53}$; na cultual integram os mesmos templos em certas localidades. ${ }^{54} \mathrm{E}$ há em ambas as tradições, bem como na epigráfica, representações armadas de Afrodite, além de epítetos marciais, vistos não raro com a desconfiança imposta pela força da tradição épico-homérica da Ilíada (5.348-9, 426-30), em que, além de ser enxotada da batalha pelo herói grego Diomedes - com auxílio de Atena, rival da deusa -, fugindo no carro que Ares, seu irmão, lhe empresta, ${ }^{55}$ Afrodite é lembrada por Zeus, seu pai, de sua esfera de atuação: não a da guerra, que cabe a Ares e a Atena, mas a "dos desejáveis trabalhos da boda" (himeróenta (...) erga gámoio, 429). Sente-se na fortuna crítica o peso dessa cena nas discussões sobre a Afrodite guerreira; veja-se como Raoul Lonis (1979, 211), em Guerre et religion en Grèce à l'époque classique, abre o comentário:

A despeito de quão paradoxal ela pareça, a deusa que Homero nos apresenta como presidindo sobretudo sobre os jogos do amor surge em vários epítetos como uma deusa guerreira. (...) e não é evidente que os muito numerosos testemunhos que associam Afrodite e Ares sejam apenas o reflexo da lenda dos amores da deusa com o deus guerreiro.

Nem se reduzem a esse reflexo da canção de Demódoco os testemunhos em que Afrodite transita de algum modo no mundo da guerra - de Atena e de Ares -, nem os invalida a cena iliádica, equivocamente tomada, afirma Pironti, como "verdadeiro 'dogma'" (2007, 210), dadas a autoridade de Homero e de Zeus, como "sanção teológica do verdadeiro caráter da Afrodite grega, de deusa do gamos [da boda], cujas competências se defi-

${ }^{53}$ Ver Delivorrias 1984, que elenca 16 imagens de Ares e Afrodite anteriores a 500 a.C.; Budin 2003, 23-8; Pirenne-Delforge e Pironti 2011, 46.

${ }^{54}$ Por exemplo, em Argos e Creta. Ver Solima 1998, 403-16; Pironti 2005, 172, 175-8; Pironti 2007, 242-72. Mas, ao contrário de Pironti, Solima rejeita, na análise da Afrodite armada, nela ver o caráter bélico, tomando antes como projeção do tema poético dos enlaces da deusa e de Ares.

${ }_{55}$ Note-se o paralelismo no canto 21 (391-425), em que Afrodite salva Ares, deus ferido por Atena. Como bem observa Pironti $(2005,181)$, Ares e Afrodite formam uma dupla na epopeia homérica, seja como irmãos e aliados (Ilíada), seja como amantes (Odisseia). 
nem por oposição à guerra, domínio que Zeus atribui a Ares e Atena" (2005, 179), a ela interdito. ${ }^{56}$ Note-se, afinal, que, na mesma Ilíada (20.38), ela adentra a guerra junto aos demais olímpicos, em favor dos troianos; estamos, claro, em plena teomaquia, mas dela Afrodite não é excluída. Seja como for, bem vale o alerta de Pironti $(2007,211)$ :

O mundo dos deuses constitui, com efeito, um conjunto flexível que se articula e se reconfigura em função dos contextos e que não se reduz à simples justaposição de divindades cujos domínios seriam estritamente delimitados de uma vez por todas. É, portanto, preferível não projetar a imagem de Afrodite que emerge da Ilíada para a análise de seus cultos, e reconhecer em cada tipo de fonte e de contexto uma autonomia relativa na declinação dessa potência divina, sob seus diferentes aspectos.

Dos testemunhos mencionados, que mostram "que a relação com a guerra fazia parte das prerrogativas atribuídas pelos gregos a Afrodite" (Pironti 2005, 177), vejamos na esfera cultual os casos mais conhecidos das ilhas de Chipre e Citera, ${ }^{57}$ de Corinto e de Esparta.

Para o caso cíprio, o tardio Léxico de Hesíquio (c. 400 d.C.) é a fonte, pois em seu verbete énkheios diz: "Aphrodítē. Kýprioi" ("da lança: Afrodite, em Chipre"). A ele se somam duas estátuas cíprias que podem ser da deusa e que talvez sejam armadas - não há clareza sobre esses dois pontos. ${ }^{58}$ Seja como for, Pirenne-Delforge, em L'Aphrodite grecque (1994, 369), conclui que o aspecto guerreiro da deusa em Chipre "é o correlato natural de seu papel de protetora da comunidade", e não prova sua dimensão bélica, para a qual inexiste "consistência cultural" (p. 471) no mundo grego. Stephanie L. Budin, em "Aphrodite Enoplion" (2010, 83), observa que "a imagem de Afrodite armada não era típica de sua iconografia em Chipre em nenhum momento de sua longa história na ilha, que remonta a circa 1450 a.C.".

Para o caso da ilha de Citera, a fonte é Pausânias (c. 115-18o d.C.) que, na Descrição da Grécia (Lacônia, 3.23.1), menciona uma estatueta (xóanon) da deusa "armada" (hōplisménos), "tema de uma série de epigramas dos quais os mais antigos são atribuídos ao poeta helenístico Leônidas de Tarento e nos quais o adorno guerreiro da deusa suscita estupefação" (Pironti

\footnotetext{
${ }^{56}$ Pironti (2007, 211-31; ver também 2010, 122) aprofunda e reitera essa crítica.

${ }^{57}$ Para as relações da deusa com as ilhas de Chipre e Citera, ver estudo detalhado e discussão de fontes primárias e secundárias em Ragusa (2005b, 83-95, 103-27).

${ }^{58}$ Para Hadjiannou (1981, 184-6; 1983, 281), são do tipo de que fala Hesíquio e projetam uma Afrodite bélica, da guerra. Já Daszewski (1983, 281-2) afirma que não são estatuetas da Afrodite "da lança". Em artigo anterior (1982, 195-202), defendia que uma é de Afrodite Urânia, dadas as vestes e o pé sob um casco de tartaruga; a outra, nua, da deusa segurando uma espada, e não uma lança, em postura de ataque $(1983,200)$. Daszewski (ibid.) comenta ainda outras imagens em que a deusa está se armando - um motivo muito explorado na iconografia helenística, e que se acham não só em Chipre, mas em Corinto e na Magna Grécia - um motivo muito explorado na iconografia helenística.
} 
2007, 231). Considera Pirenne-Delforge (1994, 223) que essa imagem pode ter "sido realizada no momento em que os espartanos dominavam" Citera, no século vi a.C., pois Afrodite tinha dimensão guerreira em Esparta. Essa explicação é defendida consistentemente, alertando contra o automatismo da explicação da deusa armada como fruto de influência oriental (p. 454) - o culto de Afrodite de Citera, note-se, teria sido trazido pelos fenícios, segundo Heródoto (c. 480-420 a.C.), nas Histórias das Guerras Pérsicas (1.105) e Pausânias (Ática, 1.14.7), em testemunhos que comentei a propósito das relações Afrodite-Oriente (Ragusa 2005b, 110-8). Sobre tal automatismo explicativo, Pironti $(2005,173)$ declara:

Para garantir a Afrodite seu título de deusa do amor e justificar, ao mesmo tempo, os indícios que a articulam ao domínio da guerra, a maior parte dos estudiosos ${ }^{59}$ sustentou a origem oriental da Afrodite armada e, por vezes revertendo a ordem do raciocínio, acreditaram ser possível demonstrar essa origem oriental apoiando-se precisamente no caráter guerreiro de Afrodite - caráter aparentemente inexplicável para uma deusa cuja ação deveria se limitar ao casamento, à beleza, ao amor-, para que ela possa ser reconhecida como totalmente grega.

Quanto ao caso de Corinto, A. C. Villing (1997, 93), em "Aspects of Athena in the Greek polis", recorda testemunhos que indicam "uma Afrodite guerreira [que] era a protetora principal da cidade" e tinha um santuário na Acrocorinto desde pelo menos o século vir a.C.: Pausânias (Corinto, 2.5.1) indica no local uma estátua (ágalma) romana da deusa hoplisméne ("armada") - como a já vista em Citera e como outra em Esparta -, que pode ou não ser cópia de original grega mais antiga, e cujas armas de Afrodite podem significar uma deusa guerreira. Isso se reforça na localização do santuário e na notícia sobre a súplica de mulheres à deusa às vésperas da Batalha de Salamina (c. 480 a.C.), entre gregos e persas, para que nos homens suscitasse "desejo de luta" (érōs tēs mákhēs). ${ }^{60}$ Analisadas as fontes dessa narrativa, Pironti $(2007,254)$, que o faz em minúcia, afirma a necessidade de se reconhecer simplesmente "o estatuto grego de divindade tutelar de Corinto e de encarar o fato de que os gregos podiam atribuir-lhe prerrogativas militares". Não há razão para negar isso, frisa a estudiosa, nem para explicações que recorrem às influências orientais tomadas quase como resíduos na imagem grega da deusa.

\footnotetext{
${ }_{59}$ Tais como Farnell 1892; Lonis 1979; Graf 1984; Burkert 1993; Flemberg 1999.

${ }^{60}$ Plutarco (c. 45-120 d.C.), Da malignidade de Heródoto (871a), que se soma a outros testemunhos comentados por Pirenne-Delforge (1994, 104-9): Ateneu (ativo em c. 200 d.C., Banquete dos sofistas 13.573c-d) e um escólio a Píndaro (Ode olímpica 13.32). A helenista, seguida por estudiosos como Villing $(1997,95)$ e Pironti $(2005,175-6)$, vê uma dimensão bélica na Afrodite da Acrocorinto.
} 
Destaco ainda, dos testemunhos, moedas coríntias dos séculos vi e v a.C., retratando uma deusa com o elmo ${ }^{61}$ - Afrodite, como propôs François Lénormant (1866, 73-7), em "Vénus armée", ou a Atena que assim se desenha em moedas da Ática da mesma época. ${ }^{62}$ Essa compreensão, em geral mais aceita, é criticada por Villing e, antes, por Peter E. Blomberg (1996, 71), em Corinthian iconography. Este revisa as evidências em análise detida, tendo em vista as características da imagem, a prevalência de Afrodite (junto a Posêidon e Apolo) no cenário cultual de Corinto, em que Atena tinha pouca relevância, e sua posição no santuário destacado da fortificada Acrocorinto. Para ele (p. 96), não é que Corinto tenha emprestado a Atena das moedas áticas, mas que tenha feito com sua deusa protetora, Afrodite, o mesmo que Atenas com a sua. ${ }^{63}$

Finalmente, no caso de Esparta, Pausânias (Lacônia, 3.15.10) é uma das fontes para a notícia do templo de "Afrodite Areía", próximo ao santuário de Atena, na acrópole, e ao das Musas. ${ }^{64}$ Se o epíteto, que ressoa o nome de Ares, qualifica Afrodite como "Ares feminino", deusa bélica, ou simplesmente alude às relações amorosas entre eles é questão debatida, mas a primeira opção se fortalece em outros testemunhos de Afrodite guerreira, relativos ao segundo templo da deusa que também projetava esse aspecto. Corroboram sua existência evidências outras que o testemunho de Pausânias (3.15.10-11), que ali insere uma estatueta (xóanon) "armada" (hoplisménē), similar às de Citera e Corinto. ${ }^{65}$ Trata-se de "uma única estatua, datada dos séculos IV-III a.C., que mostra uma mulher em peplo dórico, usando um elmo e com o braço esquerdo erguido como se para lançar uma lança", descreve Budin $(2010,86)$, para quem talvez se trate "de uma Afrodite armada". E há ainda, lembra Pirenne-Delforge (1994, 199), uma inscrição do século III d.C., que atesta o culto de Afrodite enóplios ("em armas"),

${ }^{61}$ Para descrição detalhada e imagens: Blomberg 1996, 67-70.

${ }^{62}$ Note-se que a referida proposta de Lénormant foi logo rejeitada por Imhoof-Blumer e Gardner (1885). Lénormant $(1866,74)$ sabia que se colocava contra a visão corrente desde o século XVI entre os "escritores de numismática", que consideravam que a figura era de Atena, e não de Afrodite.

${ }^{63}$ Budin $(2010,89-90,100)$ segue a postura de Blomberg quanto à identificação de Afrodite como a deusa com elmo nas moedas coríntias, aduzindo outras evidências às que ele analisa, mas considera que a imagem da deusa armada foi contaminada pela de Atena, não sendo um atributo da própria Afrodite.

${ }^{64}$ Segundo Pausânias (3.17.5), este se explica pelo fato de os espartanos irem a combate ao som do aulós (instrumento de sopro, espécie de oboé), da lira e da cítara. A existência desse templo foi confirmada pela arqueologia, que encontrou inscrição com uso do epíteto (Budin 2010, 85-6).

${ }_{65}$ Esta, dita ágalma, como destaquei é tardia, à diferença das xóana ou estatuetas de Citera e Esparta. Note-se a terminologia escolhida por Pausânias, que não é casual, pois xóanon normalmente se aplica às representações mais antigas de madeira, barro ou bronze, enquanto ágalma nomeia a estátua em mármore em geral, cuja ascensão dá-se com o "desenvolvimento da grande escultura" a partir do século vir a.C., observa Burkert (1993, 193). 
epíteto que Plutarco (c. 45-120 d.C., Moralia 239a) dá como pertencente à deusa em Esparta, e que se acha também em evidência epigráfica da era romana (c. 31 a.C. -476 d.C.). ${ }^{66}$

Tudo somado, conclui Pirenne-Delforge (p. 210) ser o "caráter militar" da Afrodite espartana "inegável", referido em diversas fontes literárias helenísticas e romanas. Mesmo Budin (2010, 112), que não acredita numa Afrodite bélica antes da era romana, afirma: "Há apenas um lugar no mundo grego antigo em que ela parece ter tido um culto arcaico como deidade bélica: Esparta". E comenta Villing (1997, 83):

Parece que havia espaço em Esparta para mais de uma deusa guerreira, embora pareça provável que as duas não preenchiam exatamente as mesmas funções. Atena possivelmente supervisionava questões de política da pólis, ${ }^{67}$ de amplo escopo, enquanto Afrodite pode ter sido valorizada pelos seus poderes menos racionais; podemos imaginá-la interessada em ritos de transição (feminina?) e possivelmente no amor homossexual entre guerreiros.

Ainda anota Villing, adiante (p. 95):

Uma Afrodite guerreira aparece não apenas em Corinto [em sua acrópole e em outros locais], mas também num santuário da acrópole de Esparta - uma coincidência notável, distinguindo essas duas cidades de boa parte da Grécia. Mas, ao contrário do que se passa em Corinto, Afrodite não parece ter superado o papel proeminente de Atena como deusa da guerra, e as duas deidades continuaram a coexistir na acrópole de Esparta.

De fato, nem em Esparta, nem na Hélade, a guerra é território dominado por Afrodite ou por ela usurpado à Atena, mas há que constatar igualmente, no mínimo, que há representações gregas de Afrodite armada e guerreira, conforme enfatiza Pironti (2010, 121), ainda que a análise aprofundada de seu sentido em todas as ocorrências dependa de evidências escassas ou mesmo indisponíveis e da relação do estudioso com o peso da imagem da deusa encerrada na fala de Zeus, na Ilíada, certamente essencial, diz Pironti, "à definição moderna de Afrodite como deidade da feminilidade e do amor, cuja esfera de influência se oporia ao mundo do homem e da guerra".

Na temática erótica, a linguagem revela antes conjunção e superposição do que oposição entre a arena da guerra e a arena de éros. Note-se, aliás, que a ideia da míxis ("mistura"), nuclear ao enlace sexual - sentido básico de gámos, termo para a boda -, é elaborada no terreno de Afrodite e no de Ares na poesia grega antiga: formas verbais de meignynai ("misturar, imiscuir") e similares designam com frequência a mistura de corpos no leito

\footnotetext{
${ }^{66}$ Ver Budin 2010, 89, 99.

${ }^{67}$ Isso além de ser deidade guerreira (Villing 1997, 89).
} 
(Ilíada 3.445; Odisseia 8.267-9) ou na batalha (Ilíada 15.510); formas verbais de damázein ("domar") e similares designam constantemente a ação de Eros, de Afrodite, do desejo (éros, hímeros, póthos) sobre seus alvos (Teogonia 122; Hino homérico 5: a Afrodite, v. 3; Fr. jâmbico 196a de Arquíloco, c. 680-640 a.C.), os sedutores, e para a destes sobre os seduzidos (Ilíada 14.315-6), ou para a ação marcial sobre o combatente inimigo (Ilíada 22.176); Afrodite é chamada a ser sýmmakhos ("aliada de lutas", v. 28) da suplicante no Fr. I de Safo - epíteto composto só aqui registrado na poesia grega; Eros chega aos mortais como as tropas chegam sobre o inimigo, atacando implacavelmente, diz a forma verbal eperkhómenon (v. 5) no Fr. 287 de Íbico, típica de contextos marciais; Eros chega com o "dardo" (bélos, v. 530) de Afrodite, "devastando, saqueando" - diz a forma verbal pérthonta (v. 541), de pérthein, que nomeia a arrasadora marcha de exércitos ou de heróis em fúria bélica homicida -, canta o "Hino a Eros" da tragédia Hipólito, de Eurípides.

Detenho-me aqui, porque a lista que ilustra a equivalência das arenas da guerra e da sedução na poesia grega antiga de temática erótica é vasta - sem exageros - e cobre os variados gêneros poéticos, pois se elabora em dicção tradicional em sua linguagem, suas imagens e seus motivos. Mas, considerando-a juntamente ao cenário da Afrodite armada na iconografia e nos cultos, podemos dizer, em consonância com Pironti (2010, 128), que a linhagem do deus Eros, filho de Afrodite e de Ares, tal qual retratada em Simônides, no Fr. 575, sua ocorrência mais antiga, posteriormente "atinge seu pleno sentido na prece endereçada à Afrodite da Acrocorinto, antes da batalha de Salamina", já referida, "para que inspirasse o 'desejo de luta' nos soldados" - o érōs tēs mákhēes, ${ }^{68}$ significando o substantivo basicamente, como frisei antes, a falta que precisa ser suprida com toda a urgência (Carson 1998, 10), seja tal falta a de comida e de bebida, como na epopeia homérica, a do corpo desejado, ou ainda a do campo de batalhas.

\section{OS EPÍTETOS DO FR. 575 E SEUS REFERENTES}

O epíteto de Afrodite, dolomēdeos ("ardilosa", v. 1), no Fr. 575 de Simônides, coaduna-se com seu caráter ardiloso de deusa da sedução, exaustivamente marcado na poesia grega antiga, e aqui já comentado a propósito da ocorrência de dolóplokos ("tecelã de ardis", v. 9) no Fr. 541 do poeta. Já o epíteto composto que se segue ao nome de Ares, dolo-mēkhánōi ("artífice

\footnotetext{
${ }^{68}$ Ver nota 60.
} 
de ardis"), está sinalizado como corrompido em sua primeira metade na edição do escólio que preservou o Fr. $575^{69}$; e do aparato crítico, da edição (Page 1962) constam emendas que presumem, conclui Malcom Davies (1984, 114-16), em "Simonides and Eros", "que o primeiro elemento do adjetivo composto tenha sido contaminado pelo epíteto precedente". Uma é kakomakhánōi ("artífice de males"), a outra, thrasymēkhánōi ("audaz em tramas") $)^{70}$ - usado apenas por Píndaro para Héracles (Ode olímpica 6.67) e o leão (Ode nemeica 4.62). Nenhuma prosperou, todavia. Mais razoável é a solução independentemente sugerida por Davies (ibid.) e Benedetto Marzullo (1984/1985, 15), em "Sim. Fr. 575 P": de que se tome o epíteto como atribuído a Eros - escrevendo-se "o simples" dolomákhanon, que, no acusativo, se articula ao filho, em vez de dolomēkhánōi que, no dativo, se liga ao pai (Árēi). Afinal, o filho é ardiloso como a mãe, Afrodite, caracterizada como tal no verso 1 do fragmento; a mudança reflete nas ações e no caráter de Eros antes a imagem da mãe do que a do pai, uma vez que, na tradição cultual, iconográfica e textual, é na esfera de atuação materna - a do sexo - que atua, e não na esfera marcial, paterna.

Assim, a construção repetitiva dolomēdeos Afrodite-dolomákhanon [tòn = Eros] nos versos 1-2 do Fr. 575 de Simônides "é altamente eficaz: a mãe planeja atos enganosos e seu filho os realiza, uma distribuição de trabalho que pode ser inferida a partir de várias passagens da literatura grega", afirma Davies (1984, 116). E Eros é chamado justamente de dolomákhanon em Teócrito (Idílio 30.25-6), observam Marzullo (ibid.) e Davies (ibid.), ambos tratando esse fato como decisivo na argumentação.

Sustenta-se, portanto, plenamente, neste cenário, a correção ao manuscrito do escólio à Argonáutica, única fonte do Fr. 575 de Simônides, tal qual defendida pelos dois helenistas. O mesmo não se pode dizer da manutenção do epíteto como se lê no manuscrito, atribuído a Ares, a qual não tem fundamentação de qualquer espécie, pois o epíteto de modo algum se coaduna com a natureza desse deus que se regozija com o massacre das batalhas, que é pura violência bélica, sendo simplesmente equivocada, como bem enfatiza Davies (1984, 115), a argumentação de George S. Farnell (1891, 370), em Greek lyric poetry, de que Ares seja dolomēkhánōi ("artífice de ardis") tendo em vista seu adultério com Afrodite na Odisseia. E equivocada por várias razões que Davies (ibid.) ressalta, entre as quais, a de que a imagem de Afrodite e Ares como amantes é bem mais rara do que como cônjuges, com-

${ }^{69}$ Wendel 1958, 216.

${ }^{70}$ A primeira (kakomakhánōi) foi sugerida por Bergk (1914, Fr. 43), e é seguida na tradução de West (1994, 166); a segunda (thrasymēkhánōi), por Wilamowitz (1913, Sappho und Simonides). No aparato crítico ao Fr. 575 de Simônides, Page (1962) apenas indica essas emendas a dolomēkhánōi. 
pleta, lembrando a Ode pítica 4.81-2, de Píndaro. ${ }^{71}$ A esta acrescentaria ainda outra: de que, no episódio do canto viıI da epopeia homérica, Ares não age de modo sofisticado, mas apenas responde ao impulso erótico por Afrodite, levando-a ao leito na ausência do marido que, este sim, age ardilosamente para armar o flagrante dos adúlteros e expô-los como tais ao Olimpo, prendendo-os em "armadilha" (dólon, 276 e 282) inescapável que ninguém via, "pois preparou-a bem dolosamente [dolóenta]" (8.281). ${ }^{72}$ E como bem observam Marcel Detienne e Jean-Pierre Vernant (2008, 253), em Métis, o coxo Hefesto, deus ferreiro, supera pela inteligência o deus da guerra que é mais veloz e forte, Ares - deus que "não tem reputação de grande sutileza: é um bruto sem sombra de métis", de inteligência astuciosa -, de forma que não é ele "a verdadeira presa do ferreiro", mas, sim, "sua cúmplice", Afrodite: "Pois a esposa de Hefesto é uma potência de astúcia e de engano: sua métis ondulante (aiolómetis), sua habilidade em estender armadilhas (doloplókos)", trazida à tona em suas imagens nos Frs. 541 e 575 de Simônides, "seu desejo insaciável de enganar e de seduzir, fazem de Afrodite uma divindade que os deuses tanto quanto os homens temem".

Considerar, portanto, que há um erro de grafia com insustentáveis implicações semânticas no caso do epíteto do verso 2 do Fr. 575 de Simônides é mais do que razoável, é necessário - e diga-se que nas fontes de transmissão direta e indireta não são raros erros textuais. Comprovar o erro, porém, é impossível, o que talvez explique a relutância de alguns estudiosos ${ }^{73}$ - ou excesso de cautela. E se falo nestes termos é porque, além de tudo o que já foi dito, há ainda outro subsídio que posso aduzir à opção pela sugestão de Marzullo (1984/1985, 15) e Davies (1984, 114-16), de tomar o epíteto negativo como atribuído a Eros, de sorte que seja este o deus "artífice de ardis" (dolomákhanon) - à imagem e semelhança de sua mãe, Afrodite, deusa dolóplokos ("tecelã de ardis") no Fr. 541 (vv. 9-10) de Simônides, como vimos, e dolomēdeos ("ardilosa") aqui mesmo no Fr. 575 -, e não seu pai, o algo tosco deus Ares, jamais qualificado em dimensão intelectual. Qual seria tal sub-

\footnotetext{
${ }^{71}$ Somente Giangrande (1969) segue Farnell, anota Davies, que os refutas. Em resenha à mínima fortuna crítica do Fr. 575, Gerber $(1994,147)$ lembra a defesa de Giangrande pela manutenção de dolomēkhánōi para Ares, com o argumento de que o deus teria o papel de "destruidor de casamentos". Mas isso não se sustenta nem mesmo se considerarmos a cena da Odisseia, uma vez que o adultério ali não destrói nada, mas é cômico, uma vez que não há tragédia no Olimpo dos deuses imortais e venturosos.

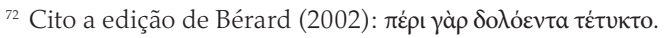

${ }^{73}$ Campbell $(1991,461)$, por exemplo, em geral muito aberto a emendas e suplementos, opta por não traduzir o problemático epíteto do verso 2, indicando as emendas no aparato e na nota à sua edição. Já Edmonds (1924, Fr. 54) mantém o epíteto, traduzindo-o como atribuído a Ares, mas indicando na nota 2: "talvez 'artífice de males'", tradução para a emenda kakomakhánōi (ver nota 70). Também Fowler $(1992,202)$ e Fuentes $(2002,13)$ traduzem o epíteto como atribuído a Ares.
} 
sídio? A própria maneira pela qual Eros é invocado, negativamente e em "elocução agressiva", enfatiza Cavallini (1986, 113), que logo transforma a prece "em pungente crítica nos confrontos com o deus, considerado como fonte de desgraças causadas por seus enganos", tal qual sua mãe, Afrodite, aqui no Fr. 575 e no 541.

Afrodite é sempre uma deidade perigosa e potencialmente tão ou mais destrutiva do que Ares ${ }^{74}$ - a Afrodite de Simônides (Frs. 541 e 575), como já a de Íbico, ainda mais do que outras precedentes, e talvez menos do que ou similar a algumas que as sucederam, como a terrível deusa da tragédia Hipólito, de Eurípides. ${ }^{75}$ Considerá-la apenas um símbolo feminino do amor, do feminino, da beleza, como faz Paul Friedrich (1978), em The meaning of Aphrodite, e como se faz no senso-comum verbalizado ou escrito é reduzir drasticamente a complexidade da deusa, é banalizá-la; e falar de sua natureza como "relativamente pacífica e amatória", como faz Friedrich $(1978,97)$, é sinal inequívoco de incompreensão, ou distorção, ou superficial e insuficiente conhecimento de sua representação poética, cultual e iconográfica na Grécia antiga - ou a mistura de tudo isso. Não é esta a Afrodite grega, mas aquela que "nos obriga a contemplar o elo entre persuasão e violência, união e conflito, concórdia e guerra, e a pensar essas relações em termos outros que os de oposição", anota Pironti (2005, 170), tais como, lembra ela (pp. 176 e 178), a intersecção testemunhada na súplica das mulheres coríntias, que pedem à deusa que acenda nos homens o desejo - éros, o poder que ela rege - de guerrear, como vimos anteriormente.

Eis a Afrodite da poesia, da iconografia, dos cultos - e nas suas tintas mais sombrias, a deusa e seu universo nos fragmentos 541 e 575 de Simônides.

\section{REFERÊNCIAS}

Adrados, F. R. 1980. Lírica grieca arcaica. Introd., trad., notas. Madri: Gredos.

Alden, M. J. 1997. "The resonances of the song of Ares and Aphrodite". Mnemosyne 50:513-29.

Anderson, S. M. M. G. 2011. “A ‘Ode a Escopas' no Protágoras de Platão.” Dissertação de Mestrado. Universidade de São Paulo.

Babut, D. 1975. "Simonide moraliste". REG 88:20-62.

Barrett, W. S., ed. 1992. Euripides Hippolytos. Oxford: Clarendon. (1 ed. 1964).

${ }^{74}$ Afirma Budin (2002, 321): "Eu às vezes me espanto que estudiosos questionem suas frequentes associações com Ares, pois ela provoca mais destruição massiva do que ele".

${ }^{75}$ Estudei-a anteriormente (Ragusa 2002/2003). 


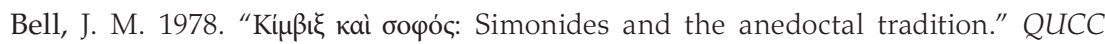
28:29-86.

Bérard, V., ed. 2002. Homère. Odyssée, chants VIII à XV. Com notas de S. Milanezi. Paris: Belles Lettres. 2 ed.

Bergk, T. ed. 1914. Poetae lyrici Graeci - III. Leipzig: Teubner. 4 ed. (1 ed. 1882).

Beresford, A. 2008. "Nobody's perfect: a new text and interpretation of Simonides PMG 542." CPh 103:237-56.

Bergren, A. L. T. 1983. "Language and the female in early Greek thought." Arethusa 16:69-95.

Bernardini, P. A. 1969. "Simonide." QUCC 8:140-66.

Blomberg, P. E. 1996. On Corinthian iconography. Uppsala: Ubsaliensis S. Academiae.

Bowra, C. M. 1961. Greek lyric poetry. Oxford: Clarendon. 2 ed.

Bowra, C. M. 1963. "Simonides or Bacchylides?” Hermes 91:257-67.

Braswell, B. K. 1982. "The song of Ares and Aphrodite." Hermes 110:129-37.

Breitenberger, B. 2007. Aphrodite and Eros. The development of erotic mythology in early Greek poetry and cult. New York: Routledge.

Broneer, O. 1930. The "armed Aphrodite" on Acrocorinth and the Aphrodite of Capua. Berkeley: University of California Press.

Brown, C. G. 1989. "Ares, Aphrodite, and the laughter of the gods." Phoenix 43:283-93.

Budin, S. L. 2002. "Creating a goddess of sex." In Engendering Aphrodite, edited by D. Bolger and N. Serwint, 315-24. Boston: American Schools of Oriental Research.

Budin, S. L. 2003. The origin of Aphrodite. Bethesda: CDL Press.

Budin, S. L. 2010. "Aphrodite Enoplion." In Brill's companion to Aphrodite, edited by S. Pickup and A. C. Smith, 51-78. Leiden: Brill.

Bundrick, S. D. 2008. "The fabric of the city: imagining textile production in classical Athens." Hesperia 77:283-334.

Burkert, W. 1993. Religião grega na época clássica e arcaica. Trad. M. J. S. Loureiro. Lisboa: Fundação Calouste Gulbenkian.

Calame, C., ed. 1983. Alcman. Roma: Ateneo.

Calame, C. 2013. Eros na Grécia antiga. Trad. I. E. Kopelman. São Paulo: Perspectiva.

Campbell, D. A., ed. 1991. Greek lyric - III. Cambridge: Harvard University Press.

Carson, A. 1992. "How not to read a poem: unmixing Simonides from Protagoras." CPh 87:110-30.

Carson, A. 1998. Eros, the bittersweet: an essay. Chicago: Dalkey Archive Press.

Carson, A. 2002. Economy of the unlost (reading Simonides of Keos with Paul Celan). Princeton: Princeton University Press. 4 ed.

Cavallini, E. 1986. Presenza di Saffo e Alceo nella poesia greca fino ad Aristofane. Ferrara. ("Quaderni del Giornale Filologico Ferrarese" 7).

Daszewski, W. A. 1982. "Aphrodite hoplismene from Nea Paphos." RDAC:195-202.

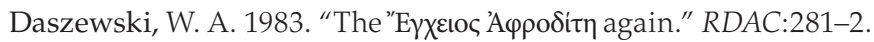

Davies, M. 1984. "Simonides and Eros." Prometheus 10:114-6.

Davies, M., ed. 1991. Poetarum melicorum Graecorum fragmenta - I. Oxford: Clarendon.

Delivorrias, A. S. et al., ed. 1984. "Aphrodite." In Lexicon Iconographicum Mythologicae Classicae - II, 2-151. Zürich: Artemis.

Detienne, M. 1964. “Simonide de Céos et la sécularisation de la poésie." REG 77:405-19. 
Detienne, M. 2013. Os mestres da verdade na Grécia arcaica. Trad. I. C. Benedetti. São Paulo: wmf Martins Fontes. (Ed. orig. 1973).

Detienne, M., e J.-P. Vernant. 2008. Métis. As astúcias da inteligência. Trad. F. Hirata. São Paulo: Odysseus. (Ed. orig. 1974).

Donlan, W. 1969. "Simonides, Fr. 4 D and P. Oxy. 2432." TAPhA 100:71-95.

Durán López, M. A. 2000. "Simonides y la crítica del lenguaje." In Actas del X Congreso Español de Estudios Clásicos (21-25 septiembre 1999) - I, editado por E. Crespo y J. B. Castro, 185-92. Madrid: Sociedad Española de Estudios Clásicos.

Edmonds, J. M., ed. 1924. Lyra Graeca - II. Cambridge: Harvard University Press.

Farnell, G. S. 1891. Greek lyric poetry. London: Longmans, Green \& Co..

Farnell, L. R. 1896. The cults of the Greek states - II. Oxford: Clarendon.

Faulkner, A. 2008. The Homeric hymn to Aphrodite. Oxford: Oxford University Press.

Flemberg, J. 1995. "The transformations of the armed Aphrodite." In Greece E gender, edited by B. Berggreen and N. Marinatos, 109-22. Bergen: The Norwegian Institute at Athens.

Fowler, B. H. 1992. Archaic Greek poetry. Madison: The University of Wisconsin Press.

Fränkel, H. 1975. Early Greek poetry and philosophy. Trad. M. Hadas e J. Willis. Oxford: Basil Blackwell. (Ed. orig. 1962).

Friedrich, P. 1978. The meaning of Aphrodite. Chicago: The University of Chicago Press.

Fuentes, C. B. 1991. "Los dioses en Simónides de Ceos." In Actas del VIII Congresso espanõl de estudios clásicos (Madrid, 23-28 de septiembre de 1991), 77-84. Madrid: Ediciones Clásicas.

Fuentes, C. B. 2002. "La expressión del sentimento amoroso en Simonides". Humanitas (Coimbra) 54:9-33.

Gantz, T. 1996. Early Greek myth. Baltimore: The Johns Hopkins University Press. 2 vols.

Garrison, D. H. 2000. Sexual culture in ancient Greece. Norman: The University of Oklahoma Press.

Gentili, B. 1961. "Recensione: 'The Oxyrhynchus papyri, part 25'." Gnomon 33:331-43.

Gentili, B. 1964. "Studi su Simonide. II. Simonide e Platone." Maia 16:278-306.

Gentili, B. 1965a. Lirica greca corale. Parma: Guanda.

Gentili, B. 1965b. "Aspetti del rapporto poeta, committente, uditorio nella lirica corale greca." StudUrb (B) 39:70-88.

Gentili, B. 2006. Poesia e pubblico nella Grecia antica. Da Omero al v secolo. Ed. revista e atualizada. Milano: Feltrinelli. (1 ed. 1985).

Gentili, B., and C. Catenacci. 2010. I poeti del canone lirico nella Grecia antica. Milano: Feltrinelli.

Gerber, D. E. 1970. Euterpe: an anthology of early Greek lyric, elegiac, and iambic poetry. Amsterdam: Adolf M. Hakkert.

Gerber, D. E. 1994. "Greek lyric poetry since 1920. Part II: from Alcman to fragmenta adespota. 10. Simonides". Lustrum 36:129-52.

Giangrande, Giuseppe. 1969. "Simonides und Eros." L'antiquité classique 38(1):147-9.

Gillies, M. M., ed. 1928. The Argonautica of Apollonius Rhodius. Book III. Cambridge: Cambridge University Press.

Graf, F. 1984. "Women, war, and warlike divinities." ZPE 55:245-54.

Hadjioannou, K. 1981. "Aphrodite in arms." RDAC:184-6. 


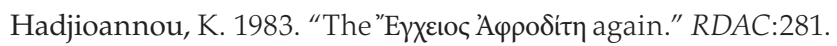

Henderson, W. J. 1999. "Imagery in Simonides." AClass 42:383-95.

Henry, W. B. 1998. "Simonides, PMG 541." ZPE 121:303-4.

Holmberg, I. E. 1997. “The sign of Mñтı." Arethusa 30:1-33.

Hutchinson, G. O. 2003. Greek lyric poetry. Oxford: Oxford University Press.

Imhoof-Blumer, F., and P. Gardner. 1885. "Numismatic commentary on Pausanias I." JHS 6:50-101.

Jenkins, I. D. 1985. "The ambiguity of Greek textiles." Arethusa 18:109-32.

Kondoleon, C. 2011. "Eros, child of Aphrodite." In Aphrodite and the gods of love, edited by C. Kondoleon and P. C. Segal, 107-47. Boston: MFA Publications.

Konstantakos, I. M. 2012. "Demodocus' song of Ares and Aphrodite and the mythicization of an adultery tale." Maia 64:12-34.

Lefkowitz, M. R. 1981. The lives of the Greek poets. London: Duckworth.

Lenormant, F. 1866. "Vénus armée sur les monnaies de Corinthe." RN 11:73-7.

Lesky, A. 1995. História da literatura grega. Trad. M. Losa. Lisboa: Fundação Calouste Gulbenkian. (Ed. orig. 1957).

Lloyd, G. E. R. 1971. Polarity and analogy: two types of argumentation in early Greek thought. Cambridge: Cambridge University Press.

Lloyd-Jones, H. 1961. "Review of The Oxyrhynchus Papyri XXV." CR 11:17-21.

Lloyd-Jones, H. 1971. The justice of Zeus. Berkeley: University of California Press.

Lobel, E. 1959. "2432. Simonides?" In The Oxyrhynchus papyri, part XXV, edited by E. Lobel, E. G. Turner and R. P. Winnington-Ingram, 91-4. London: Egypt Exploration Society.

Lonis, R. 1979. Guerre et religion en Grèce à l'époque classique. Paris: Belles Lettres.

Marzullo, B. 1984/1985. “Simon. Fr. 575 P." MCr 19/20:15.

Mazon, P., ed. 2002a. Homère. Iliade, chants I à VIIII. Préface par J.-P. Vernant. Notes par H. Monsacré. Paris: Belles Lettres. 2 ed.

Mazon, P., ed. 2002b. Homère: Iliade, chants IX à XVI. Notes par H. Monsacré. Paris: Belles Lettres. 2 ed.

Mazon, P., ed. 2008. Hésiode. Theogonie. Introd. et notes par G. Pironti. Paris: Belles Lettres.

Mooney, G., ed. 1964. The Argonautica of Apollonius Rhodius. Amsterdam: Adolf M. Hakkert.

Most, G. W. 1995. “L'odi di Simonide a Scopas nei suoi contesti." In Poesia greca, a cura di Graziano Arrighetti, 137-69. Pisa: Giardini Editori e Stampatori.

Olson, S. D. 1989. "Odyssey 8." Arethusa 22:135-45.

Nock, A. D. 1924. "Eros the child." CR 38:152-5.

Page, D. L., ed. 1962. Poetae melici Graeci. Oxford: Clarendon Press.

Pantelia, M. C. 1993. "Spinning and weaving: ideas of domestic order in Homer." AJPh 114:493-501.

Parry, H. 1978. "An interpretation of Simonides 4 (Diehl)." TAPhA 96:297-320.

Pellicia, H. 2009. "Simonides, Pindar and Bacchylides." In The Cambridge companion to Greek lyric, edited by F. Budelmann, 240-62. Cambridge: Cambridge University Press. 
Pellizer, E. 1978. "“... E il bello e il turpe distingue': Simonide, fr. 36 PMG 541." QUCC 28:87-91.

Perrotta, G., B. Gentili e C. Catenacci. 2007. Polinnia. Poesia greca arcaica. Messina, Firenze: Casa Editrice G. D'Anna. 3 ed. rev. e ampl.

Pfeiffer, R. 1998. A history of classical scholarship - I. Oxford: Clarendon. (1 ed. 1968).

Pirenne-Delforge, V. 1994. L'Aphrodite grecque. Athènes, Liège: CIERGA.

Pirenne-Delforge, V., and G Pironti. 2011. "Greek cults of Aphrodite." In Aphrodite and the gods of love, edited by C. Kondoleon and P. C. Segal, 41-61. Boston: MFA Publications.

Pironti, G. 2005. "Aphrodite dans le domaine d'Arès." Kernos 18:167-84.

Pironti, G. 2007. Entre ciel et guerre. Figures d'A phrodite en Grèce ancienne. Liège: CIERGA.

Pironti, G. 2010. "Rethinking Aphrodite as a goddess at work." In Brill's companion to Aphrodite, edited by Amy C. Smith and Sadie Pickup, 113-29. Leiden: Brill.

Ragusa, G. 2002/2003. "Cólera, paixão e morte: a representação de Afrodite no Hipólito, de Eurípides." Clássica 15/16:79-98.

Ragusa, G. 2005a (2001). "Da castração à formação: a gênese de Afrodite na Teogonia." Letras Clássicas 5:109-30.

Ragusa, G. 2005b. Fragmentos de uma deusa: a representação de Afrodite na lírica de Safo. Campinas: Editora da Unicamp. (Apoio: Fapesp).

Ragusa, G. 2010. Lira, mito e erotismo: Afrodite na poesia mélica grega arcaica. Campinas: Editora da Unicamp. (Apoio: Fapesp).

Ragusa, G. 2011. Safo de Lesbos. Hino a Afrodite e outros poemas. São Paulo: Hedra.

Ragusa, G. 2013. Lira grega: antologia de poesia arcaica. São Paulo: Hedra.

Robbins, E. 1997. "Public poetry." In A companion to the Greek lyric poets, edited by D. E. Gerber, 221-88. Leiden: Brill.

Rodrigues Jr., F. 2005. “Epopeia e Poesia Alexandrina: Estudo e Tradução do Canto III das Argonáuticas de Apolônio de Rodes." Dissertação de Mestrado. Universidade de São Paulo.

Rosenmeyer, T. G. 1951. "Eros - Erotes.” Phoenix 5:11-22.

Segal, C. 1990. "Choral lyric in the fifth century." In The Cambridge History of classical literature, I: Greek literature, edited by P. E. Easterling and B. W. Knox, 222-44. Cambridge: Cambridge University Press.

Snell, B., ed. 1964. Pindarus - pars altera: fragmenta. Leipzig: Teubner. 3 ed.

Snyder, Jane M. 1981. "The web of song: weaving imagery in Homer and the Lyric Poets." The Classical Journal 76(3):193-96.

Stampolidis, N. Chr., and Y. Tassoulas, ed. 2009. Eros. From Hesiod's Theogony to late antiquity. Athens: Museum of Cycladic Art.

Solima, I. 1998. "Era, Artemide e Afrodite in Magna Grecia e in Grecia. Dee armate o dee belliche?" MEFRA 110(1):381-417.

Suhr, E. G. 1960. "The spinning Aphrodite in sculpture". AJA 64:253-64.

Suhr, E. G. 1963. "The spinning Aphrodite in the minor arts". AJA 67:63-8.

Suhr, E. G. 1969. The spinning Aphrodite. The evolution of the goddess from earliest pre-Hellenic symbolism through late classical times. New York: Helios Books.

Teffeteller, A. 2010. "The song of Ares and Aphrodite: Ašertu on Skheria." In Brill's companion to Aphrodite, edited by Amy C. Smith and Sadie Pickup, 133-50. Leiden: Brill. 
Treu, Max. 1960. "Neues zu Simonides (P. Ox. 2432)." Rheinisches Museum für Philologie 103:319-36.

Villing, A. C. 1997. "Aspects of Athena in the Greek polis: Sparta and Corinth." In What is a God? Studies in the nature of Greek divinity, edited by A. B. Lloyd, 81-100. London: Duckworth, The Classical Press of Wales.

Voigt, E.-M. ed. 1971. Sappho et Alcaeus. Amsterdam: Athenaeum, Polak \& Van Gennep.

Wendel, C. ed. 1958. Scholia in Apollonium Rhodium vetera. Berlin: Weidmanm.

West, M. L. trans. 1994. Greek lyric poetry. Oxford: Oxford University Press.

West, M. L. ed. 1998. Iambi et elegi Graeci. Oxford: Oxford University Press. 2 vols. (1 ed. 1971).

\section{$*$}

Title. Aphrodite in Simonides (frs. 541 and 575 P)

Abstract. In the melic corpus of Simonides, active in late archaic Greece, we find only two fragments naming Aphrodite: the precarious 541 and the small 575 P, both woven with features that are either recurrent in archaic poetry or are not previously found. This article will turn to these features, in order to study Aphrodite's image in Simonides's melic poetry.

Keywords. Simonides; late archaic Greek melic; Aphrodite; fragments. 